\title{
Methylosarcina lacus sp. nov., a methanotroph from Lake Washington, Seattle, USA, and emended description of the genus Methylosarcina
}

Correspondence

Ludmila Chistoserdova milachis@u.washington.edu

\author{
Marina G. Kalyuzhnaya, ${ }^{1}$ Sergey M. Stolyar, ${ }^{2}$ Ann J. Auman, ${ }^{3}$ \\ Jimmie C. Lara, ${ }^{4}$ Mary E. Lidstrom ${ }^{1,4}$ and Ludmila Chistoserdova ${ }^{1}$ \\ ${ }^{1,2,4}$ Department of Chemical Engineering ${ }^{1}$, Department of Civil and Environmental Engineering ${ }^{2}$ \\ and Department of Microbiology4, University of Washington, Seattle, WA 98195, USA
}

${ }^{3}$ Department of Biology, Pacific Lutheran University, Tacoma, WA 98447, USA
Obligate methanotrophs are a specialized group of bacteria capable of utilizing methane as the sole source of carbon and energy. These bacteria play a major role in the global cycling of methane, oxygen and nitrogen (King, 1992; Hanson \& Hanson, 1996) and have a potential for use in biotechnology as biodegradation and bioremediation agents (Higgins et al., 1980; Oremland et al., 1994; Bodrossy et al., 1995). Methanotrophic bacteria are widespread in natural habitats and are found in soils, wetlands and sediments as well as in fresh, saline and alkaline waters (Whittenbury et al., 1970; Hanson \& Hanson, 1996).

Analysis of methanotrophic populations in Lake Washington revealed that a broad diversity of methanotrophic species is present (Costello \& Lidstrom, 1999; Auman et al., 2000; Auman \& Lidstrom, 2002); they may represent up to $30 \%$ of the total bacterial population in the site (Costello

Published online ahead of print on 1 July 2005 as DOI 10.1099/ ijs.0.63405-0.

Abbreviations: MMO, methane monooxygenase; RuMP, ribulose monophosphate.

The GenBank/EMBL/DDBJ accession number for the 16S rRNA gene sequence of strain $\mathrm{LW}_{14}{ }^{\top}$ is $\mathrm{AY} 007296$. et al., 2002). Pure cultures of both type I and type II methanotrophs have been isolated from the site and have been shown to be related closely to known groups of methanotrophic bacteria belonging to the genera Methylomonas, Methylobacter, Methylosinus and Methylocystis (Auman et al., 2000). According to cultureindependent analysis of the methylotrophic community in Lake Washington, one of these phylotypes, isolate $\mathrm{LW} 14^{\mathrm{T}}$, represented one of the dominant groups in this site (Kalyuzhnaya et al., 2004). On the basis of phylogenetic analysis, isolate $\mathrm{LW} 14^{\mathrm{T}}$ was classified as a member of the genus Methylobacter, with a 16S rRNA gene sequence similarity level of about $95 \%$ to representatives of the genus Methylobacter (Auman et al., 2000). In a later publication, a novel genus, Methylosarcina, was proposed to accommodate two novel methanotrophic isolates, from soils, that possess divergent $16 \mathrm{~S}$ rRNA genes and peculiar morphological and biochemical features (Wise et al., 2001). Close relatedness of the 16S rRNA gene sequence from isolate $\mathrm{LW} 14^{\mathrm{T}}$ to the sequences of the newly described Methylosarcina species (96\% similarity) prompted us to conduct a taxonomic analysis of isolate $\mathrm{LW} 14^{\mathrm{T}}$. Isolate $\mathrm{LW} 14^{\mathrm{T}}$, characterized here, is the first example of a Methylosarcina species from an aquatic environment. 
Strain $\mathrm{LW} 14^{\mathrm{T}}$ was grown at $30^{\circ} \mathrm{C}$ in $0 \cdot 25$ or 11 flasks containing 25 or $100 \mathrm{ml}$ NMS minimal medium (Whittenbury et al., 1970), respectively. Cultures were shaken (at 200 r.p.m.) for 3-5 days under a methane/air atmosphere $(1: 1)$. Cultures were maintained on solid NMS medium containing $1.5 \%(w / v)$ Difco agar under a methane/air atmosphere (1:1) for 3-6 days. For long-term storage, $100 \mu \mathrm{l}$ DMSO was added to $1 \mathrm{ml}$ exponentially growing liquid culture and the mixed suspension was stored at $-80^{\circ} \mathrm{C}$. The following strains were used as controls: Methylosarcina fibrata DSM $13736^{\mathrm{T}}$ and Methylosarcina quisquiliarum DSM $13737^{\mathrm{T}}$ [obtained from the Deutsche Sammlung von Mikroorganismen und Zellkulturen (DSMZ), Braunschweig, Germany], 'Methylobacter bovis' VKM B-2112, 'Methylobacter chroococcum' VKM B-2114 and 'Methylobacter vinelandii' VKM B-2113 [obtained from the All-Russian Collection of Micro-organisms (VKM), Pushchino, Russia] and Methylomicrobium album ACM $3314^{\mathrm{T}}$ (Lidstrom laboratory collection). The cultures were grown under methane/air in the NMS medium described above.

For transmission electron microscopy, cells were washed with double-distilled water and fixed in modified Karnovsky's fixative (2\% paraformaldehyde, $2.5 \%$ gluteraldehyde,

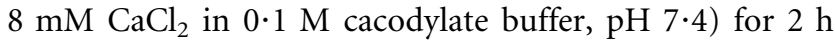
at $4{ }^{\circ} \mathrm{C}$. Samples were washed in cacodylate buffer and postfixed in $1 \%$ osmium tetroxide in buffer for $2 \mathrm{~h}$ at room temperature. Following three $5 \mathrm{~min}$ washes, cells were embedded in $1.5 \%$ Noble agar (Difco) and dehydrated in a graded series of ethanol $(35,50,70,80,90,95,100 \%)$. Blocks were then infiltrated at three concentrations of propylene oxide: Spurr's resin $(2: 1 ; 1: 1 ; 1: 3$, respectively), ending with $100 \%$ Spurr's resin. Thin sections of samples were stained with $7 \%$ uranyl acetate and Reynolds' lead citrate for 20 and $10 \mathrm{~min}$ each, respectively. Samples were viewed by using an 1200 Ex II transmission electron microscope (JEOL) operated at $80 \mathrm{kV}$. For scanning electron microscopy, cells were fixed as described above, washed three times for $5 \mathrm{~min}$ with double-distilled water, spotted onto plastic coverslips coated with $1 \%$ poly-L-lysine, dehydrated in a graded series of ethanol to $100 \%$, then subjected to critical-point drying. Samples were sputtercoated with gold/palladium and viewed with a JSM 6300F scanning electron microscope (JEOL) at $15 \mathrm{kV}$. The microscopy revealed large, non-motile, coccobacillary cells, $0 \cdot 7-1 \cdot 0 \mu \mathrm{m}$ in width and $1 \cdot 0-1 \cdot 2 \mu \mathrm{m}$ in length (Fig. 1a, $b, c)$. Cells usually occurred singly or in pairs, but sometimes formed chains of three to five cells (Fig. 1b, c). Typical cells had one distinct feature: a holdfast-like structure,

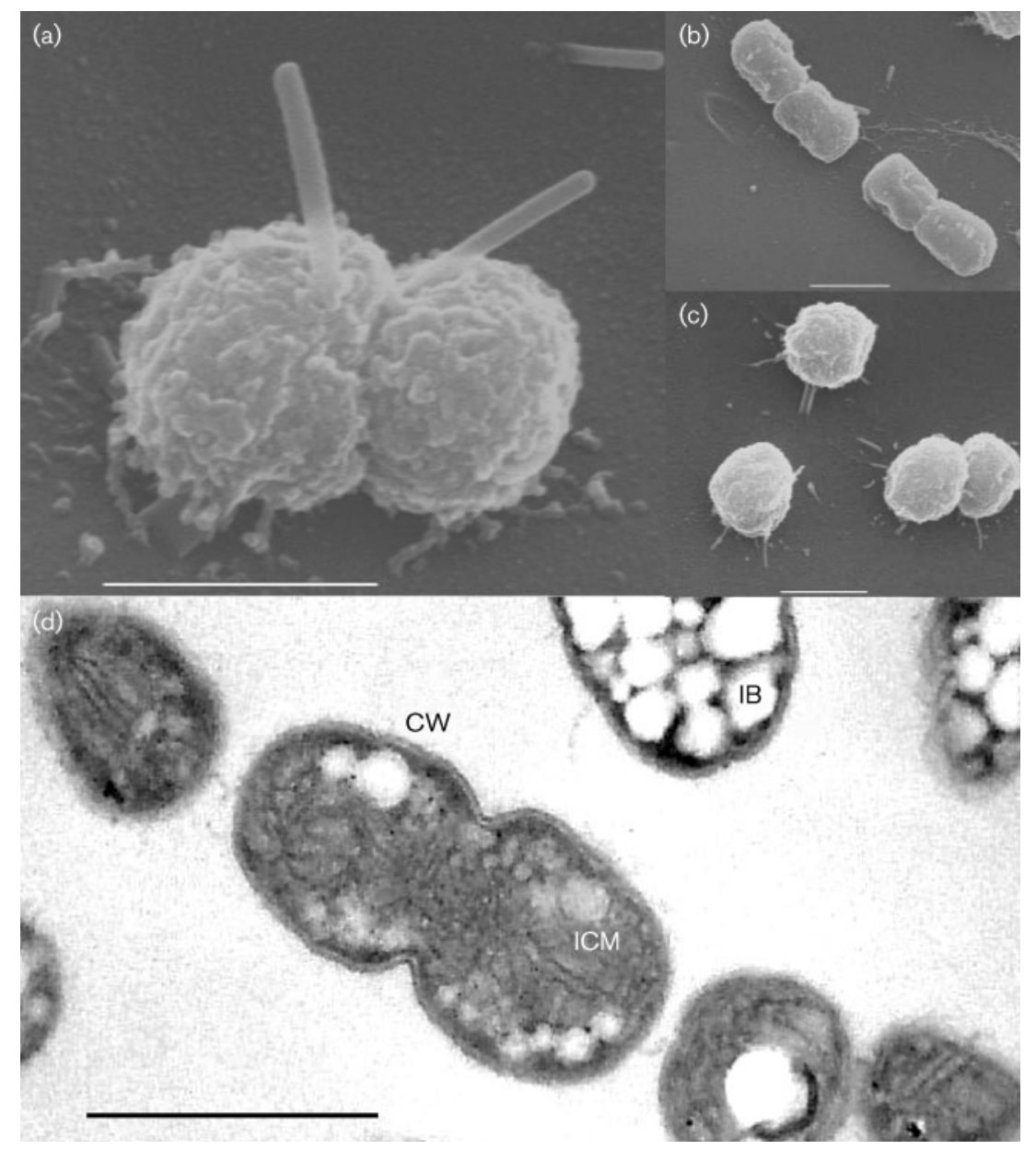

Fig. 1. Scanning $(\mathrm{a}-\mathrm{c})$ and transmission (d) electron micrographs of LW14 ${ }^{\mathrm{T}}$ cells. (a) Individual cells with holdfast-like structures; (b, c) individual cells and pairs of ovoid or coccoid cells; (d) thin-sectioned cells showing type I cell-wall structure (CW), internal cytoplasmic membranes (ICM) and large inclusion bodies (IB). Bars, $1 \mu \mathrm{m}$. 
$0 \cdot 8-1 \cdot 0 \mu \mathrm{m}$ in length and $0 \cdot 2-0 \cdot 3 \mu \mathrm{m}$ in width (Fig. 1a). Cells reproduced by binary fission and did not visibly form cysts or other resting bodies. Thin sectioning showed that cells had a Gram negative-type cell-wall structure, and internal membranes typical of type I methanotrophs (Fig. 1d).

The growth-substrate range was tested in liquid NMS medium supplemented with one of the following autoclaved or filter-sterilized substrates $(0.05 \% \mathrm{w} / \mathrm{v})$ : methylamine, formate, dimethylsulfate, vanillin, choline, betaine, oxaloacetate, acetate, pyruvate, citrate, malate, succinate, glucose, maltose, fructose, sucrose, mannitol, ethanol, glycerol, serine, valine, alanine, cysteine, asparagine, arginine, aspartate, methionine, histidine, tryptophan and yeast extract. The ability to grow on methanol was tested at concentrations of $0 \cdot 01-1 \%(\mathrm{v} / \mathrm{v})$. Methane or methanol, but no other substrates tested, supported growth of isolate LW14 ${ }^{\mathrm{T}}$. In the case of methanol, maximal growth occurred when cells were grown at low concentrations $(<0 \cdot 1 \%$ methanol, v/v), with optimal growth occurring at $0.05 \%(\mathrm{v} / \mathrm{v})$. Nitrogen sources were tested by using solid medium in which $\mathrm{KNO}_{3}$ had been replaced by one of the following compounds, at $0.05 \%(\mathrm{w} / \mathrm{v}):\left(\mathrm{NH}_{4}\right)_{2} \mathrm{SO}_{4}$, methylamine, urea, guanidine, glycine, serine, valine, alanine, cysteine, asparagine, arginine, aspartate, methionine, histidine, threonine, proline, glutamate, phenylalanine, tryptophan, peptone or yeast extract. For $\mathrm{N}_{2}$-fixation experiments, a nitrate-free medium was used. Isolate $\mathrm{LW} 14^{\mathrm{T}}$ used nitrates, urea, serine, aspartate and glutamate as nitrogen sources, but was unable to grow in the absence of a fixed nitrogen source, suggesting that it cannot fix $\mathrm{N}_{2}$. The inability to detect the nifH gene, which encodes the $\mathrm{Fe}$ protein of nitrogenase, has been reported previously for this strain (Auman et al., 2001).

Heat resistance was tested by heating cell suspensions at $50,60,70$ or $80^{\circ} \mathrm{C}$ for $10 \mathrm{~min}$, then plating them onto solid medium and incubating them at optimal conditions for 2 weeks. Desiccation resistance was assessed according to Whittenbury et al. (1970). Sensitivity to antibiotics was examined by spreading appropriate dilutions of the culture onto solid medium and placing, on top of the cultures, paper discs (Difco) that contained one of the following antibiotics $\left(\mu \mathrm{g} \mathrm{ml}^{-1}\right)$ : neomycin (30), kanamycin (30), ampicillin (10), penicillin (10), erythromycin (15), lincomycin (2), gentamicin (10), novobiocin (30), nalidixic acid (30), tetracycline (30), chloramphenicol (30) or streptomycin (10). Growth under methane was assessed after 2 weeks. The optimum $\mathrm{pH}$ and temperature were investigated in liquid medium. A mixture $(0.05 \mathrm{M})$ of $\mathrm{NaH}_{2} \mathrm{PO}_{4} / \mathrm{Na}_{2} \mathrm{HPO}_{4}$ was used for buffering ( $\mathrm{pH} 4 \cdot 2-8 \cdot 5)$.

After 5 days growth on agar plates under a methane/air atmosphere, colonies of isolate $\mathrm{LW} 14^{\mathrm{T}}$ were white, $1-2 \mathrm{~mm}$ in diameter, circular, convex and smooth. In liquid cultures, cells tended to clump together, forming white flakes. The specific growth rate in liquid cultures under methane/air was $0.05 \pm 0.003 \mathrm{~h}^{-1}$. The strain grew at temperatures ranging from 4 to $35^{\circ} \mathrm{C}$, with optimal growth occurring at
$28-30{ }^{\circ} \mathrm{C}$. Isolate $\mathrm{LW} 14^{\mathrm{T}}$ was not resistant to heat, desiccation or freeze-drying under the conditions tested. Isolate LW $14^{\mathrm{T}}$ was found to be catalase-positive, resistant to nalidixic acid, streptomycin, tetracycline, chloramphenicol, penicillin and ampicillin, and sensitive to erythromycin, novobiocin, neomycin, kanamycin, lincomycin and gentamicin, at the concentrations tested.

Activities of enzymes characteristic of major methylotrophic pathways were tested. For cell-free extract preparation, $\mathrm{LW} 14^{\mathrm{T}}$ cells grown under methane/air were pelleted by centrifugation at 5000 r.p.m. at $4{ }^{\circ} \mathrm{C}$, resuspended in $1 \mathrm{ml}$ Tris $(25 \mathrm{mM}$ Tris/HCl, $10 \mathrm{mM}$ EDTA, $\mathrm{pH} 7 \cdot 2)$ or phosphate $\left(25 \mathrm{mM} \mathrm{KH} \mathrm{KO}_{4} / \mathrm{Na}_{2} \mathrm{HPO}_{4}, \mathrm{pH} 7 \cdot 2\right)$ buffer and disrupted by passage through a French pressure cell at $1 \cdot 2 \times 10^{8} \mathrm{~Pa}$. Cell extracts were centrifuged at 14000 r.p.m. for $25 \mathrm{~min}$ at $4{ }^{\circ} \mathrm{C}$ to remove cell debris. Hydroxypyruvate reductase and serine-glyoxylate aminotransferase were assayed as described by Goodwin (1990). Hexulose phosphate synthase was assayed as described by Shishkina et al. (1976). Phosphoribulokinase and ribulose bisphosphate carboxylase/oxygenase (RuBisCo) were assayed as described by Tabita (1980). Formate dehydrogenase was assayed as described by Chistoserdova et al. (2004). Methylene tetrahydrofolate dehydrogenase was assayed as described by Vorholt et al. (1998). The soluble methane monooxygenase (MMO) test was performed by using naphthalene oxidation (Bodrossy et al., 1995); soluble MMO activity in whole-cell suspensions was measured by using a fluorescence-based assay (Miller et al., 2002). Whilst the activity of particulate MMO was detected (Table 1), the tests for soluble MMO activity were negative, confirming previous studies (Auman et al., 2000). A high level of activity for hexulose phosphate synthase, the key enzyme of the ribulose monophosphate (RuMP) cycle for formaldehyde assimilation (Anthony, 1982), was detected (Table 1), whereas activities of key enzymes of the serine cycle (hydroxypyruvate reductase and serine-glyoxylate aminotransferase) or

Table 1. Enzyme activities in cell extract of isolate $L W 14^{\top}$

All activity determinations were carried out in triplicate. ND, Not detectable.

\begin{tabular}{|lc|}
\hline Enzyme & $\begin{array}{c}\text { Activity [nmol min } \\
(\mathbf{m g} \text { protein })^{-1}\end{array}$ \\
\hline Particulate MMO & $68 \pm 4$ \\
Soluble MMO & $\mathrm{ND}$ \\
Hexulose phosphate synthase & $120 \pm 15$ \\
Hydroxypyruvate reductase & $\mathrm{ND}$ \\
Serine-glyoxylate aminotransferase & $\mathrm{ND}$ \\
RuBisCo & $\mathrm{ND}$ \\
Phosphoribulokinase & $\mathrm{ND}$ \\
Methylene tetrahydrofolate & $70 \pm 5$ \\
dehydrogenase & \\
Formate dehydrogenase & $25 \pm 5$ \\
\hline
\end{tabular}


the ribulose bisphosphate cycle (RuBisCo and phosphoribulokinase) were not detected. High enzyme activity for methylene tetrahydrofolate dehydrogenase was detected, which is indicative of the presence of the $\mathrm{H}_{4} \mathrm{~F}$-linked pathway for $\mathrm{C}_{1}$ transfer (Vorholt et al., 1999). Although we were not able to test for the activities of key enzymes of the $\mathrm{H}_{4} \mathrm{MPT}$ pathway that has been shown to be widespread in methylotrophs (Vorholt et al., 1999), because of the lack of availability of the substrate, we have previously detected the presence of the $m c h, m t d B$ and fae genes, which code for key enzymes of the $\mathrm{H}_{4} \mathrm{MPT}$-linked pathway (Vorholt et al., 1998, 1999; Hagemeier et al., 2000; Vorholt et al., 2000), via PCR amplification (Kalyuzhnaya et al., 2004).

Phospholipid fatty acid analyses were performed by Microbial Insights (http://www.microbe.com/). Lipids were recovered by using the modified Bligh-Dyer method (White et al., 1979). The membrane fatty acid profile determined for isolate $\mathrm{LW} 14^{\mathrm{T}}$ is shown in Table 2: the major components were $\mathrm{C}_{16: 1} \omega 8 c \quad(33 \%), \mathrm{C}_{16: 1} \omega 5 t$ $(26 \cdot 9 \%)$ and $\mathrm{C}_{16: 1} \omega 7 c(18 \%)$.

For DNA extraction and purification, cells ( $5 \mathrm{~g}$ wet weight) were resuspended in lysis buffer $(10 \mathrm{mM} \mathrm{NaCl} ; 20 \mathrm{mM}$ Tris/HCl, pH 8.0; 1 mM EDTA; $100 \mathrm{mg}$ proteinase $\mathrm{K} \mathrm{ml}^{-1}$; $50 \mathrm{mg}$ ribonuclease $\mathrm{A} \mathrm{ml}^{-1} ; 0 \cdot 5 \%(\mathrm{w} / \mathrm{v}) \mathrm{SDS}$ - all from Sigma) and incubated overnight. DNA was purified by phenol/chloroform extraction and ethanol precipitation (Sambrook et al., 1989). The DNA G +C content was determined by HPLC separation, performed in triplicate, as described by Tamaoka \& Komagata (1984). DNA-DNA hybridization experiments were performed by using the competition procedure described by Johnson (1994). The following strains were tested: LW14 ${ }^{\mathrm{T}}$, Methylosarcina fibrata, Methylosarcina quisquiliarum, 'Methylosarcina methanica', 'Methylobacter bovis', 'Methylobacter chroococcum'

Table 2. Major fatty acids of type I methanotrophic genera and isolate $\mathrm{LW} 14^{\mathrm{T}}$

Taxa: 1, Methylomonas; 2, Methylobacter; 3, Methylomicrobium; 4, Methylococcus; 5, Methylosarcina; 6, LW14 ${ }^{\mathrm{T}}$. NR, Not reported; $\mathrm{ND}$, not detectable.

\begin{tabular}{|lcccccc|}
\hline Fatty acid & $\mathbf{1}^{\star}$ & $\mathbf{2}^{\star}$ & $\mathbf{3}^{*}$ & $\mathbf{4}^{\star}$ & $\mathbf{5} \dagger$ & $\mathbf{6}$ \\
\hline $\mathrm{C}_{12: 0}$ & $\mathrm{NR}$ & $\mathrm{NR}$ & $\mathrm{NR}$ & $\mathrm{NR}$ & $3 \cdot 0 \pm 0 \cdot 4$ & $\mathrm{NR}$ \\
$\mathrm{C}_{14: 0}$ & $22 \pm 3$ & $9 \pm 2$ & $1 \pm 1$ & $<1$ & $1 \cdot 5 \pm 0 \cdot 5$ & $1 \cdot 1$ \\
$\mathrm{C}_{16: 1} \omega 8 c$ & $30 \pm 11$ & $\mathrm{ND}$ & $16 \pm 3$ & $\mathrm{ND}$ & $15 \pm 1$ & $33 \cdot 6$ \\
$\mathrm{C}_{16: 1} \omega 7 c$ & $11 \pm 4$ & $57 \pm 1$ & $17 \pm 3$ & $28 \pm 10$ & $28 \pm 3$ & $18 \cdot 2$ \\
$\mathrm{C}_{16: 1} \omega 6 c$ & $9 \pm 4$ & $5 \pm 1$ & $10 \pm 4$ & $3 \pm 2$ & $8 \pm 1$ & $8 \cdot 3$ \\
$\mathrm{C}_{16: 1} \omega 5 c$ & $4 \pm 2$ & $7 \pm 1$ & $6 \pm 1$ & $3 \pm 2$ & $<1$ & $\mathrm{ND}$ \\
$\mathrm{C}_{16: 1} \omega 5 t$ & $12 \pm 4$ & $11 \pm 1$ & $20 \pm 10$ & $<1$ & $25 \pm 5$ & $26 \cdot 9$ \\
$\mathrm{C}_{16: 0}$ & $7 \pm 2$ & $8 \pm 1$ & $15 \pm 3$ & $44 \pm 8$ & $19 \pm 1$ & $9 \cdot 9$ \\
\hline
\end{tabular}

${ }^{\star}$ Data from Bowman et al. (1993).

$\dagger$ Data from Wise et al. (2001). and Methylomicrobium album. DNA $(1 \mu \mathrm{g})$ from isolate LW $14^{\mathrm{T}}$ was labelled with $\left[{ }^{3} \mathrm{H}\right] \mathrm{dCTP}$ (Amersham Biosciences) by using a nick translation kit (Roche). Competitor DNA was digested by using a combination of PstI and HindIII restriction enzymes (New England Biolabs). DNA extracted from control strains ( $1 \mathrm{mg}$ ) was immobilized onto $0 \cdot 22 \mu \mathrm{m}$ Nytran N membranes (Schleicher \& Schuell) and hybridized with the labelled LW1 $14^{\mathrm{T}}$ DNA [specific activity, $5 \times 10^{6}$ d.p.m. $\left(3 \times 10^{8} \mathrm{~Bq}\right) \mu \mathrm{g}^{-1}$ ], as described by Sambrook et al. (1989). After hybridization, filters were counted in a liquid scintillation counter (Beckman) and the percentage of hybridization was calculated as described by Johnson (1994). Three independent tests were carried out for each pair of DNA preparations. Fragments of $16 \mathrm{~S}$ rRNA genes were amplified by using the primers and protocols described by Lane (1991). DNA sequencing was carried out by using a BigDye 3.1 termination sequencing kit (Applied Biosystems). Analyses were performed by the Department of Biochemistry Sequencing Facility at the University of Washington, using an ABI 3700 high-throughput capillary DNA analyser. For phylogenetic analysis, DNA sequences were aligned by using the CLUSTAL W program (Higgins et al., 1996). Phylogenetic analyses were carried out by using the PHYLIP package (Felsenstein, 2003). Distance and parsimony methods were employed and 1000 bootstrap analyses were performed.

The DNA analysis revealed that the $\mathrm{G}+\mathrm{C}$ content of the DNA is $53 \cdot 3 \pm 0 \cdot 4 \mathrm{~mol} \%(n=3)$. The nearly complete sequence of the $16 \mathrm{~S}$ rRNA gene showed $96 \%$ similarity to that of the Methylosarcina species, but only 94-95\% similarity to that of the Methylobacter species. The results of the phylogenetic analyses performed by using the $16 \mathrm{~S}$ rRNA gene sequences suggested that isolate $\mathrm{LW} 14^{\mathrm{T}}$ was related most closely to the Methylosarcina species, with high bootstrap support (Fig. 2). DNA-DNA hybridization analysis revealed low levels of similarity with representatives of the genera Methylomonas, Methylobacter and Methylomicrobium $(<3 \%)$, whilst the values for DNA-DNA hybridization with the two species of Methylosarcina - M. fibrata and $M$. quisquiliarum - were 17 and $25 \%$, respectively.

The genus Methylosarcina was proposed (Wise et al., 2001) to describe type I methanotrophs that diverge from representatives of previously described genera. The two novel species representing this genus, M. fibrata and $M$. quisquiliarum, were both isolated from soils and both possess the peculiar feature of having cells that assemble into irregularly shaped, retractile cell packets resembling sarcinalike clusters (Wise et al., 2001). Here, we characterize a novel freshwater-lake methanotrophic isolate, $\mathrm{LW} 14^{\mathrm{T}}$, and propose it to be the third representative of the genus Methylosarcina, on the basis of 16S rRNA gene sequencing and total DNA-DNA similarity. However, morphologically, isolate $\mathrm{LW} 14^{\mathrm{T}}$ differs from the two previously described Methylosarcina species. First, we did not observe any sarcina-like structures in liquid or plate cultures of isolate LW14 ${ }^{\mathrm{T}}$, at any growth stage. Cells were observed singly or 


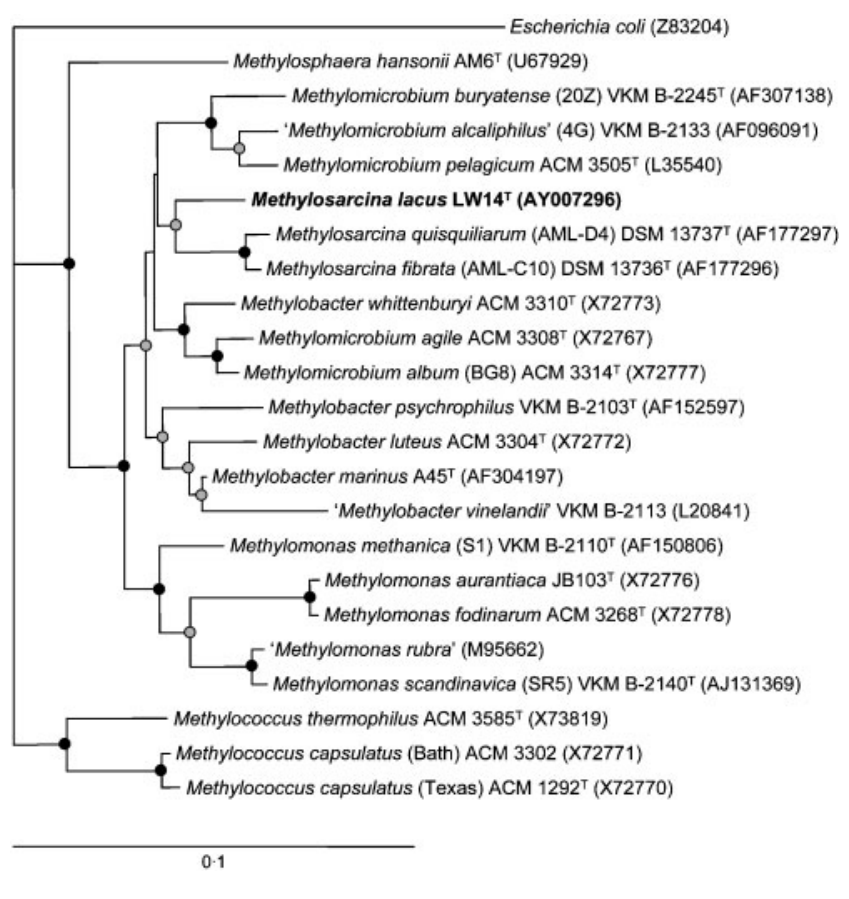

Fig. 2. Phylogenetic tree showing the relationship of isolate LW $14^{\top}$ to type I methanotrophic bacteria, based upon 16S rRNA gene sequences. Strain numbers and GenBank accession numbers (in parentheses) are shown. Solid circles indicate bootstrap support above $90 \%$ and shaded circles indicate bootstrap support above $75 \%$. Bar, $10 \%$ sequence divergence.

in pairs, and occasionally in chains of three to five cells. Additionally, LW $14^{\mathrm{T}}$ cells have a characteristic feature, namely the presence of a holdfast-like structure (Fig. 1) not previously seen in any known methanotrophic bacteria. The molecular content and physiological purpose of these holdfast-like structures remain unknown. Possibly they are involved in cell adhesion, and, if so, might play a role in the environmental fitness of bacteria associated with sediments. Physiologically, isolate $\mathrm{LW} 14^{\mathrm{T}}$ is a typical type I methanotroph capable of growth on methane and exhibiting poor growth on methanol. It utilizes particulate MMO for methane oxidation and does not possess soluble MMO. Formaldehyde is oxidized by the $\mathrm{H}_{4} \mathrm{MPT}$ linked oxidative pathway. An alternative $\mathrm{H}_{4} \mathrm{~F}$-linked pathway may also participate in formaldehyde oxidation. Formaldehyde is assimilated via the RuMP cycle. In general, the metabolic-pathway pattern determined for isolate LW14 ${ }^{\mathrm{T}}$ is typical of known type I methanotrophs (Anthony, 1982; Vorholt et al., 1999). The cellular fatty acid composition of strain $\mathrm{LW} 14^{\mathrm{T}}$ is comparable with previously published data for type I methanotrophs (Bowman et al., 1995; Wise et al., 2001), but it shows certain differences with respect to the known profiles. The most dominant fatty acid is $\mathrm{C}_{16: 1} \omega 8 c$, which is typical of representatives of the genus Methylomonas, but, unlike Methylomonas, isolate LW $14{ }^{\mathrm{T}}$ also possesses small amounts of the fatty acid $\mathrm{C}_{14: 0}$. The second dominant fatty acid in the polar lipid composition of isolate $\mathrm{LW} 14^{\mathrm{T}}$ is $\mathrm{C}_{16: 1} \omega 5 t$, which is characteristic of representatives of the genera Methylosarcina and Methylomicrobium; however, levels of palmitic acid are lower in isolate $\mathrm{LW} 14^{\mathrm{T}}$.

On the basis of the morphological features, which differ from those of described species of the genus Methylosarcina, the moderate degree of $16 \mathrm{~S}$ rRNA gene sequence similarity $(96 \%)$ and the overall low level of DNA-DNA similarity ( $25 \%$ or less), we propose that isolate $\mathrm{LW} 14^{\mathrm{T}}$ belongs to a novel taxon at the species level, for which we propose the name Methylosarcina lacus sp. nov. As M. lacus possesses traits different from those described for the previously identified Methylosarcina species, an emended description of the genus Methylosarcina is presented here.

\section{Emended description of the genus Methylosarcina}

The genus description is as given by Wise et al. (2001), but with the following additions. Colonies may be white. Cells may not form sarcina-like aggregations. Cells may be coccobacillary, occurring singly or in pairs, sometimes forming chains of three to five cells. Cells may be nonmotile, but form a holdfast-like structure. Cells may not form cysts or other resting bodies.

\section{Description of Methylosarcina lacus sp. nov.}

Methylosarcina lacus (la'cus. L. gen. n. lacus of a lake).

Cells are Gram-negative, non-motile coccobacilli, with a mean width and length of $0 \cdot 7-1 \cdot 0$ and $1 \cdot 0-1 \cdot 2 \mu \mathrm{m}$, respectively. Reproduces by binary fission. Cells form holdfast-like structures that measure $0 \cdot 8-1 \cdot 0 \mu \mathrm{m}$ in length and $0 \cdot 2-0 \cdot 3 \mu \mathrm{m}$ in width. Type I intracytoplasmic membranes are present. Colonies grown on mineral salts medium under a methane/air atmosphere are white, uniform, 1-2 mm in diameter, circular, convex and smooth. Utilizes only methane and methanol via the RuMP cycle, and appears to lack soluble MMO. Nitrate, serine, aspartate and glutamate can be used as nitrogen sources. Catalasepositive, lacks the ability to fix nitrogen and grows within a temperature range of $4-35^{\circ} \mathrm{C}$ and a $\mathrm{pH}$ range of $4 \cdot 0-7 \cdot 0$, with optimal growth at $28-30{ }^{\circ} \mathrm{C}$ and $\mathrm{pH} 5 \cdot 5-6 \cdot 5$. Not resistant to heating, freezing or drying. Major fatty acids are $\mathrm{C}_{16: 1} \omega 8 c, \mathrm{C}_{16: 1} \omega 7 c$ and $\mathrm{C}_{16: 1} \omega 5 t$. The DNA G + C content is $53 \cdot 3 \pm 0 \cdot 4 \mathrm{~mol} \%$.

The type strain, $\mathrm{LW}^{\mathrm{T}}{ }^{\mathrm{T}}\left(=\mathrm{ATCC}\right.$ BAA $-1047^{\mathrm{T}}=\mathrm{JCM}$ $13284^{\mathrm{T}}$ ), was isolated from Lake Washington, Seattle, Washington, USA.

\section{Acknowledgements}

This research was supported by a grant from the NSF Microbial Observatories Program (MCB-0131957). 


\section{References}

Anthony, C. (1982). The Biochemistry of Methylotrophs. London: Academic Press.

Auman, A. J. \& Lidstrom, M. E. (2002). Analysis of sMMO-containing Type I methanotrophs in Lake Washington sediment. Environ Microbiol 4, 517-524.

Auman, A. J., Stolyar, S., Costello, A. M. \& Lidstrom, M. E. (2000). Molecular characterization of methanotrophic isolates from freshwater lake sediment. Appl Environ Microbiol 66, 5259-5266.

Auman, A. J., Speake, C. C. \& Lidstrom, M. E. (2001). nifH sequences and nitrogen fixation in type I and type II methanotrophs. Appl Environ Microbiol 67, 4009-4016.

Bodrossy, L., Murrell, J. C., Dalton, H., Kalman, M., Puskas, L. G. \& Kovacs, K. L. (1995). Heat-tolerant methanotrophic bacteria from the hot water effluent of a natural gas field. Appl Environ Microbiol 61, 3549-3555.

Bowman, J. P., Sly, L. I., Nichols, P. D. \& Hayward, A. C. (1993). Revised taxonomy of the methanotrophs: description of Methylobacter gen. nov., emendation of Methylococcus, validation of Methylosinus and Methylocystis species, and a proposal that the family Methylococcaceae includes only the group I methanotrophs. Int J Syst Bacteriol 43, 735-753.

Bowman, J. P., Sly, L. I. \& Stackebrandt, E. (1995). The phylogenetic position of the family Methylococcaceae. Int J Syst Bacteriol 45, 182-185.

Chistoserdova, L., Laukel, M., Portais, J.-C., Vorholt, J. A. \& Lidstrom, M. E. (2004). Multiple formate dehydrogenase enzymes in the facultative methylotroph Methylobacterium extorquens AM1 are dispensable for growth on methanol. J Bacteriol 186, 22-28.

Costello, A. M. \& Lidstrom, M. E. (1999). Molecular characterization of functional and phylogenetic genes from natural populations of methanotrophs in lake sediments. Appl Environ Microbiol 65, 5066-5074.

Costello, A. M., Auman, A. J., Macalady, J. L., Scow, K. M. \& Lidstrom, M. E. (2002). Estimation of methanotroph abundance in a freshwater lake sediment. Environ Microbiol 4, 443-450.

Felsenstein, J. (2003). Inferring Phylogenies. Sunderland, MA: Sinauer Associates.

Goodwin, P. M. (1990). Assay of assimilatory enzymes in crude extracts of serine pathway methylotrophs. Methods Enzymol 188, 361-365.

Hagemeier, C. H., Chistoserdova, L., Lidstrom, M. E., Thauer, R. K. \& Vorholt, J. A. (2000). Characterization of a second methylene tetrahydromethanopterin dehydrogenase from Methylobacterium extorquens AM1. Eur J Biochem 267, 3762-3769.

Hanson, R. S. \& Hanson, T. E. (1996). Methanotrophic bacteria. Microbiol Rev 60, 439-471.

Higgins, I. J., Best, D. J. \& Hammond, R. C. (1980). New findings in methane-utilizing bacteria highlight their importance in the biosphere and their commercial potential. Nature 286, 561-564.

Higgins, D. G., Thompson, J. D. \& Gibson, T. J. (1996). Using CLUSTAL for multiple sequence alignments. Methods Enzymol 266, 383-402.
Johnson, J. L. (1994). Similarity analysis of DNAs. In Methods for General and Molecular Bacteriology, pp. 655-682. Edited by P. Gerhardt, R. G. E. Murray, W. A. Wood \& N. R. Krieg. Washington, DC: American Society for Microbiology.

Kalyuzhnaya, M. G., Lidstrom, M. E. \& Chistoserdova, L. (2004). Utility of environmental primers targeting ancient enzymes: methylotroph detection in Lake Washington. Microb Ecol 48, 463-472.

King, G. M. (1992). Ecological aspects of methane oxidation, a key determinant of global methane dynamics. Adv Microbial Ecol 12, 431-468.

Lane, D. J. (1991). 16S/23S rRNA sequencing. In Nucleic Acid Techniques in Bacterial Systematics, pp. 115-175. Edited by E. Stackebrandt \& M. Goodfellow. Chichester: Wiley.

Miller, A. R., Keener, W. K., Watwood, M. E. \& Roberto, F. F. (2002). A rapid fluorescence-based assay for detecting soluble methane monooxygenase. Appl Microbiol Biotechnol 58, 183-188.

Oremland, R. S., Miller, L. G., Culberson, C. W., Connell, T. L. \& Jahnke, L. (1994). Degradation of methyl bromide by methanotrophic bacteria in cell suspensions and soils. Appl Environ Microbiol 60, 3640-3646.

Sambrook, J., Fritsch, E. F. \& Maniatis, T. (1989). Molecular Cloning: a Laboratory Manual, 2nd edn. Cold Spring Harbor, NY: Cold Spring Harbor Laboratory.

Shishkina, V. N., lurchenko, V. V., Romanovskaia, V. A., Malashenko, lu. R. \& Trotsenko, lu. A. (1976). Alternativity of methane assimilation pathways in obligate methylotrophs. Mikrobiologiia 45, 417-419 (in Russian).

Tabita, F. R. (1980). Pyridine nucleotide control and subunit structure of phosphoribulokinase from photosynthetic bacteria. J Bacteriol 143, 1275-1280.

Tamaoka, J. \& Komagata, K. (1984). Determination of DNA base composition by reverse-phase high-performance liquid chromatography. FEMS Microbiol Lett 25, 125-128.

Vorholt, J. A., Chistoserdova, L., Lidstrom, M. E. \& Thauer, R. K. (1998). The NADP-dependent methylene tetrahydromethanopterin dehydrogenase in Methylobacterium extorquens AM1. J Bacteriol 180, 5351-5356.

Vorholt, J. A., Chistoserdova, L., Stolyar, S. M., Thauer, R. K. \& Lidstrom, M. E. (1999). Distribution of tetrahydromethanopterindependent enzymes in methylotrophic bacteria and phylogeny of methenyl tetrahydromethanopterin cyclohydrolases. J Bacteriol 181, 5750-5757.

Vorholt, J. A., Marx, C. J., Lidstrom, M. E. \& Thauer, R. K. (2000). Novel formaldehyde-activating enzyme in Methylobacterium extorquens AM1 required for growth on methanol. J Bacteriol 182, 6645-6650.

White, D. C., Davis, W. M., Nickels, J. S., King, J. D. \& Bobbie, R. J. (1979). Determination of the sedimentary microbial biomass by extractable lipid phosphate. Oecologia 40, 51-62.

Whittenbury, R., Phillips, K. C. \& Wilkinson, J. F. (1970). Enrichment, isolation and some properties of methane-utilizing bacteria. J Gen Microbiol 61, 205-218.

Wise, M. G., McArthur, J. V. \& Shimkets, L. J. (2001). Methylosarcina fibrata gen. nov., sp. nov. and Methylosarcina quisquiliarum sp. nov., novel type I methanotrophs. Int J Syst Evol Microbiol 51, 611-621. 